\title{
Genetic polymorphisms in CYP1A1 and GSTM1 predispose humans to PCBs/PCDFs-induced skin lesions
}

\author{
Pei Chien Tsai ${ }^{\mathrm{a}, \mathrm{b}}$, Wenya Huang ${ }^{\mathrm{c}}$, Yeu-Chin Lee ${ }^{\mathrm{a}}$, \\ Shih Huang Chan ${ }^{\mathrm{d}}$, Yueliang Leon Guo ${ }^{\mathrm{a}, \mathrm{e}, *}$

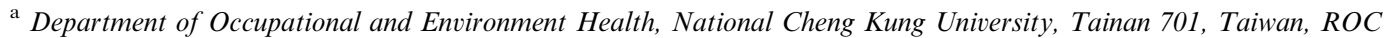 \\ ${ }^{\mathrm{b}}$ Department of Basic Medical Sciences, National Cheng Kung University, Tainan 701, Taiwan, ROC \\ ${ }^{\mathrm{c}}$ Department of Medical Technology, National Cheng Kung University, Tainan 701, Taiwan, ROC \\ d Department of Statistics, National Cheng Kung University, Tainan 701, Taiwan, ROC \\ e Department of Environmental and Occupational Medicine, National Taiwan University Medical College, \\ No. 1, Sec. 1, Jei-ai Road, Taipei 100, Taiwan, ROC
}

Received 25 April 2005; received in revised form 3 August 2005; accepted 15 August 2005

Available online 3 April 2006

\begin{abstract}
Introduction: Polychlorinated biphenyls (PCBs) and dibenzofurans (PCDFs) are ubiquitous persistent pollutants in humans. Whether people with different genotypes are with different susceptibility to these chemicals are unknown. In a group of people highly exposed to PCBs/PCDFs, we tested the hypothesis that genotypic polymorphisms affected susceptibility for development of skin manifestations.

Methods: In 1979, approximately 2000 people in central Taiwan ingested cooking oil contaminated with PCBs/ PCDFs. Skin disorder such as chloracne, abnormal nail, hyperkeratosis and skin allergy were found in PCBs/PCDFs exposed group. We recruited exposed and community background exposure subjects for blood testing and telephoneinterview. Single nucleotide polymorphisms, AhR Arg554Lys, CYP1A1 Ile462Val, CYP1A1 T6235C, and GSTM1/T1 deletion, were determined. Occurrence of skin manifestations was compared among people with different genotypes while stratified by PCB exposure levels by logistic regression.

Results: Data on exposure, medical history, and genotypes were obtained from 393 exposed and 181 background exposure groups. Skin manifestations including chloracne, allergy, abnormal nail, and hyperkeratosis were more prevalent in exposed people in a dose-related manner. Among highly exposed individuals, combined CYP1A1-MspI mutant genotype and GSTM1-null genotype were associated with increased risk of chloracne (odds ratio $2.8,95 \%$ confidence interval 1.1-7.6). Among intermediately exposed individuals, GSTM1 null genotype was associated with skin allergy. AhR Arg554Lys genotype and GSTT1 null genotype were not related to susceptibility to skin manifestations in $\mathrm{PCB} / \mathrm{PCDF}$-exposed population.
\end{abstract}

Conclusion: CYP1A1 and GSTM1 genotypic polymorphisms might be related to the susceptibility to PCB/PCDFinduced skin manifestations.

(C) 2005 Elsevier Ltd. All rights reserved.

\footnotetext{
* Corresponding author. Address: Department of Environmental and Occupational Medicine, National Taiwan University Medical College, No. 1, Sec. 1, Jei-ai Road, Taipei 100, Taiwan, ROC. Tel.: +886 922557708; fax: +886 62743748.

E-mail addresses: pctsai@ms35.url.com.tw (P.C. Tsai), leonguo@mail.ncku.edu.tw (Y.L. Guo).
} 
Keywords: Polychlorinated biphenyls; Polychlorinated dibenzofurans; Chloracne; Skin allergy; Single nucleotide polymorphism

\section{Introduction}

Polychlorinated dibenzodioxins (PCDDs), polychlorinated dibenzofurans (PCDFs), and polychlorinated biphenyls (PCBs) are ubiquitous environmental pollutants found in many environmental media and biological samples from human populations (Kimbrough, 1985; Jensen, 1987; Anderson, 1989). PCBs became recognized as potentially harmful environmental contaminants in the 1970s, and their use and manufacture were prohibited in many countries. Despite the ban on PCBs and cautious monitoring and control of dioxinlike chemicals, PCBs, PCDFs and PCDDs will be found in the environment many years to come due to their long half lives in the environment (Kimbrough, 1985). World Health Organization (WHO) has published recommendation on total daily intake of less than $1-4 \mathrm{pg}$ toxic equivalency (TEQ)/kg body weight/day based on 2,3,7,8-tetrachloro-dibenzo-p-dioxin (TCDD) (Van Leeuwen et al., 2000). Although an uncertainty factor of 10 was taken into consideration, genotype-related individual susceptibility was not, probably due to relative lacking of detailed genetic susceptibility information.

Genetic polymorphisms might play some roles in human susceptibility to dioxin-like chemicals. Aryl hydrocarbon receptor (AhR) has been known as a ligand-activated receptor for TCDD and dioxin-like chemicals, such as coplanar PCB congeners and PCDFs (Reyes et al., 1992). The toxic potency of dioxin and PCB congeners is highly related to binding affinity to AhR. Three AhR genotype polymorphism sites belong to transactivation domain of exon 10 on chromosome 7, including coden 554 (Argine to Lysine), 570 (Valine to Isoleucine) and 517 (Proline to Serine). AhR plays an important role to activate the transcription of xenobiotic metabolization as well as other genes (e.g., Cytochrome p450 family). In cultured human lymphocytes, combined Ile570 and Lys554 mutant genotypes were associated with higher TCDD-induced CYP1A1 expression, but such association was not shown on Lys554 mutant genotype only (Wong et al., 2001). In Asians, polymorphisms in coden 517 and 570 were rather rare.

The two most frequently reported CYP1A1 genotype polymorphic sites included thymine to cytosine (T to C) transition at position 6235, creating an additional cleavage site for MspI and a replacement of adenine by guanine (A to $\mathrm{G}$ ) or isoleucine to valine (Ile to Val) at position 4889, which could be digested by $\mathrm{NcoI}$ restriction enzyme. The polymorphisms (T6235C and A4889G) mentioned above were found associated with the inter-individual differences in activity of arylhydro- carbon hydroxylase $(\mathrm{AHH})$, which was one of the CYP1A1 enzymes (Landi et al., 1994; Persson et al., 1997). In animals and cultured human lymphocytes, CYP1A1 and 1B1 expression were induced by TCDD treatment (Vanden Heuvel et al., 1993; Spencer et al., 1999; Shimada et al., 2002).

Glutathione-S-transferase (GST) enzymes conjugate hydrophobic and electrophilic compounds with reduced glutathione to detoxify these chemicals (Evans and Relling, 1999; Yuspa and Shields, 2001). Among the GST enzyme family, genetic polymorphisms on GSTM1 and GSTT1, involving deletion of 20 base pairs, respectively (Seidegard et al., 1986; Pemble et al., 1994), result in deficiencies in the enzyme activities. Accumulated evidences have suggested associations between GSTM1 null genotype and various cancers, including smokinginduced lung cancer, bladder cancer, colon cancer, and breast cancer (Alexandrie et al., 1994; Anttila et al., 1994; d'Errico et al., 1996); and between GSTT1 null genotype and smoking-induced chromosome aberrations (el-Zein et al., 1997) and bladder cancer (Sorsa et al., 1996). Theses genetic polymorphisms are therefore considered important susceptibility markers for environmental toxicants.

In 1979, over 2000 people in central Taiwan ingested cooking oil contaminated with PCBs/PCDFs. The episode was later called Yucheng ("oil disease" in Chinese). The victims were estimated to consume an average of $1 \mathrm{~g}$ of PCBs and $3.8 \mathrm{mg}$ of PCDFs totally during an average of nine months of exposure to the contaminated oil (Lan et al., 1981). Among their clinical manifestations, dermatological symptoms were most frequently reported, including chloracne, hyperkeratosis, abnormal nail, and skin allergy (Guo et al., 1999). These were similar to those found in the Japanese Yusho ("oil disease" in Japanese) population (Kuratsune et al., 1971; Nakayama et al., 1997).

In this study, we test the hypothesis that genetic polymorphisms of AhR, CYP1A1 and GSTM1/T1 are associated with skin manifestations in people highly exposed to $\mathrm{PCBs} / \mathrm{PCDFs}$.

\section{Materials and methods}

\subsection{Study population}

In 1993, 795 Yucheng subjects and 693 background exposure subject were telephone-interviewed for complete medical history, as detailed in the previous study (Guo et al., 1999). Yucheng subjects reported more chloracne, hyperkeratosis, abnormal nails, and skin 
allergy than the background exposure groups. Among them, 405 Yucheng individuals had serum levels of PCBs analyzed in 1980-1982 by means of packedcolumn, electron-capture gas chromatography and an adaptation of the Webb-McCall method to a computer data system in which PCBs (Kanechlor 500) were used as reference standards. Background exposure subjects had mean serum PCB levels of $1.67 \mathrm{ppb}$ wet weight as previously reported (Guo et al., 1997). We recruited these subjects for genotype determination between 2000 and 2003.

\subsection{Genotype determination}

DNA was isolated from peripheral blood lymphocyte by phenol-chloroform extraction. The polymerase chain reaction combined with restriction fragment length polymorphism (PCR/RFLP) was used for the genetic polymorphism analysis for AhR and CYP1A1. To detect AhR single nucleotide polymorphism, DNA $(0.5 \mu \mathrm{g})$ samples were amplified in $50 \mu \mathrm{l}$ reaction mixture containing $0.4 \mu \mathrm{M}$ of each primer (Table 1), $1 \mathrm{U}$ Taq DNA polymerase (AmpliTaq; Perkin Elmer) and $0.15 \mu \mathrm{M}$ of dNTP (Boehringer Mannheim GmbH, Mannheim, Germany). The PCR reactions were performed with an initial denaturation at $95^{\circ} \mathrm{C}$ for $3 \mathrm{~min}$, followed by 30 cycles at $95^{\circ} \mathrm{C}$ for $30 \mathrm{~s}, 58^{\circ} \mathrm{C}$ for $30 \mathrm{~s}$, and $72{ }^{\circ} \mathrm{C}$ for $30 \mathrm{~s}$, and a final extension at $72{ }^{\circ} \mathrm{C}$ for $10 \mathrm{~min}$. Amplification products were digested with MseI at $37^{\circ} \mathrm{C}$ for $3 \mathrm{~h}$ and then were analyzed on a $4 \%$ Nusieve 3:1 agarose gel (BMA, Rockland, ME USA). The amplification product contained a MseI site which can be detected in all individuals and was used as an internal control for the restriction enzyme activity. The $126 \mathrm{bp}$ DNA fragment amplified from homozygous wild type was digested into two lengths: $92 \mathrm{bp}$ and $34 \mathrm{bp}$ (Arg/
Arg) while the fragment from homozygous rare allele had three bands: $71 \mathrm{bp}, 34 \mathrm{bp}$ and $21 \mathrm{bp}$ (Lys/Lys).

The CYP1A1 gene polymorphisms were separately amplified with the 2 pairs of primers (A and $\mathrm{B}$ ) as shown in Table 1. PCR/RFLP profiles were based on the method of Hayashi et al. (1991) and Shields et al. (1993). For primers pair A, when an MspI restriction site was present, the $340 \mathrm{bp}$ PCR product would be digested into two lengths: $140 \mathrm{bp}$ and $200 \mathrm{bp}$. Homozygous wild type $(\mathrm{m} 1 / \mathrm{m} 1)$ lacked MspI cutting site. The 195 bp DNA fragment amplified with CYP1A1 primers pair B from homozygous wild type individual would be digested into two lengths: $163 \mathrm{bp}$ and $32 \mathrm{bp}$ (Ile/Ile) with NcoI. The homozygous rare allele (Val/Val) lacked the NcoI digestion site had the large parent bands.

Genetic polymorphism analysis for the GSTM1 and GSTT1 genes was determined simultaneously in a single assay using a multiplex PCR approach based on the method of Arand et al. (1996). The DNA sample was amplified with 3 pairs of primers as shown in Table 1 . The PCR produced three DNA fragments of $215 \mathrm{bp}$ (GSTM1), $350 \mathrm{bp}$ (albumin) and $480 \mathrm{bp}$ (GSTT1). In both GSTM1 and GSTT1 polymorphisms, gene deletion were responsible for the existence of null alleles. Individuals homozygous with respect to a given null allele lack the respective PCR amplified DNA fragment. Thus, Albumin was used as an internal control for the PCR efficiency.

\subsection{Statistical analysis}

We entered the data in JMP 5.0 software (SAS Company) for statistical analysis. Serum levels of PCBs collected in 1980-1982 were classified into intermediate and high levels by median of PCB exposure level $(51 \mathrm{ppb})$. The prevalence of each of the four diseases

Table 1

PCR assay primers, product sizes and RFLP enzymes sites

\begin{tabular}{|c|c|c|c|c|}
\hline Gene & $\begin{array}{l}\text { Primers } \\
\left(5^{\prime}-3^{\prime}\right)\end{array}$ & Sequence & $\begin{array}{l}\text { PCR product } \\
\text { (bp) }\end{array}$ & $\begin{array}{l}\text { Detection } \\
\text { enzyme }\end{array}$ \\
\hline AhR & $\begin{array}{l}\text { Forward } \\
\text { Reverse }\end{array}$ & $\begin{array}{l}\text { GAA TCT TGG ACA TAC GTC AG } \\
\text { AGG CAT TGA TTT TGA AGA CATT }\end{array}$ & 126 & MseI \\
\hline CYP1A1 PairA & $\begin{array}{l}\text { Forward } \\
\text { Reverse }\end{array}$ & $\begin{array}{l}\text { CAG TGA AGA GGT GTA GCC GC } \\
\text { TAG GAG TCT TGT CTC ATG CC }\end{array}$ & 340 & $\begin{array}{l}\text { MspI } \\
\text { NcoI }\end{array}$ \\
\hline CYP1A1 PairB & $\begin{array}{l}\text { Forward } \\
\text { Reverse }\end{array}$ & $\begin{array}{l}\text { GAA CTG CCA CTT CAG CTG TCT } \\
\text { CCA GGA AGA GAA AGA CCT CCC AGC GGG CCA }\end{array}$ & 195 & NcoI \\
\hline GSTM1 & $\begin{array}{l}\text { Forward } \\
\text { Reverse }\end{array}$ & $\begin{array}{l}\text { GAA CTC CCT GAA AAG CTA AAG C } \\
\text { GTT GGG CTC AAA TAT ACG G TG G }\end{array}$ & 215 & Null \\
\hline GSTT1 & $\begin{array}{l}\text { Forward } \\
\text { Reverse }\end{array}$ & $\begin{array}{l}\text { TTC CTT ACT GGT CCT CAC ATC TC } \\
\text { TCA CCG GAT CAT GGC CAG CA }\end{array}$ & 480 & Null \\
\hline Albumin & $\begin{array}{l}\text { Forward } \\
\text { Reverse }\end{array}$ & $\begin{array}{l}\text { GCC CTC TGC TAA CAA GTC CTA C } \\
\text { GCC CTA AAA AGA AAA TCG CCA-ATC }\end{array}$ & 350 & Internal control \\
\hline
\end{tabular}


among background, intermediate, and high exposure groups was compared by Chi-square test. The difference of allele frequencies in Yucheng and background exposure group was determined with Chi-square test for five genetic polymorphisms. We performed logistic regression analysis to determine relationship between single gene and each disease, as well as double genes and each disease, when controlled for exposure level. Odds ratio (OR) and 95\% confidence intervals (CI) were calculated.

\section{Results}

\subsection{Demographic characteristics}

A completely telephone interview for 795 Yucheng subjects and 693 matched background exposure subjects were obtained, and the lifetime prevalence of chloracne, abnormal nails, hyperkeratosis, skin allergy, liver dis- eases and other symptoms in 1993 were recorded. Among them, 574 subjects (393 Yucheng and 181 background exposure) had genetic polymorphisms determined (Fig. 1). Table 2 compared the demographic and personal characteristics of Yucheng and background exposure groups. Stratified with sex, there is no significant difference in age, education level, smoking and consumption of alcoholic beverages in both groups. The median of PCB exposure levels in 1980-1982 $(51 \mathrm{ppb})$ was far higher than that in pooled serum sample from general population $(1.67 \mathrm{ppb})$ collected in 1992.

\subsection{Dose-response relationship between PCB level and health effects}

Among all subjects, 518 could be classified by PCB level in 1980-1982 into three groups, included 181 background exposure group; 169 with intermediate exposure



Fig. 1. Numbers of individuals in Yucheng exposed and background exposure group with genotype analysis and successful interviews in this investigation as of 1 January 2002. ${ }^{*}$ Subjects in relatively remote districts and those districts that had one or two exposed subjects, that follow-up for them was considered difficult and financially impossible. 
Table 2

Demographic and personal characteristics of Yucheng and background exposure subjects of 1993 in Taiwan

\begin{tabular}{|c|c|c|c|c|c|c|}
\hline \multirow[t]{2}{*}{ Sex exposure } & \multicolumn{3}{|l|}{ Male } & \multicolumn{3}{|l|}{ Female } \\
\hline & $\begin{array}{l}\text { Yucheng } \\
(n=176)\end{array}$ & $\begin{array}{l}\text { Background } \\
(n=100)\end{array}$ & $P$-value & $\begin{array}{l}\text { Yucheng } \\
(n=217)\end{array}$ & $\begin{array}{l}\text { Background } \\
(n=81)\end{array}$ & $P$-value \\
\hline $\operatorname{Age}(y r)^{a}$ & $50.8 \pm 0.9$ & $53.1 \pm 1.2$ & 0.1 & $45.4 \pm 0.8$ & $47.5 \pm 1.3$ & 0.2 \\
\hline $30-39(\%)$ & 22 & 18 & & 48 & 36 & \\
\hline $40-49(\%)$ & 21 & 20 & & 14 & 21 & \\
\hline $50-59(\%)$ & 29 & 28 & 0.7 & 24 & 25 & 0.2 \\
\hline$>60(\%)$ & 28 & 34 & & 14 & 18 & \\
\hline Education $(\mathrm{yr})^{\mathrm{a}}$ & $6.9 \pm 0.3$ & $7.1 \pm 0.4$ & 0.7 & $5.3 \pm 0.3$ & $6.1 \pm 0.5$ & 0.1 \\
\hline Ever smoked $^{\mathrm{b}}$ & $106(60.6 \%)$ & $67(67.0 \%)$ & 0.3 & $2(1.0 \%)$ & $4(4.9 \%)$ & 0.1 \\
\hline Ever drinking $^{\mathrm{b}}$ & $93(52.9 \%)$ & $50(50.0 \%)$ & 0.4 & $21(10.7 \%)$ & $11(13.6 \%)$ & 0.3 \\
\hline PCB level $(\mathrm{ppb})^{\mathrm{c}}$ & 57.4 & - & & 48.0 & - & \\
\hline
\end{tabular}

${ }^{a}$ Age and years of education were compared by unpaired $t$-test (mean \pm standard).

b Age distribution, smoking history and consumption of alcoholic beverages were compound by chi-square test (values in parentheses are percent).

c PCB levels were measured by median of level in 1980-1982.

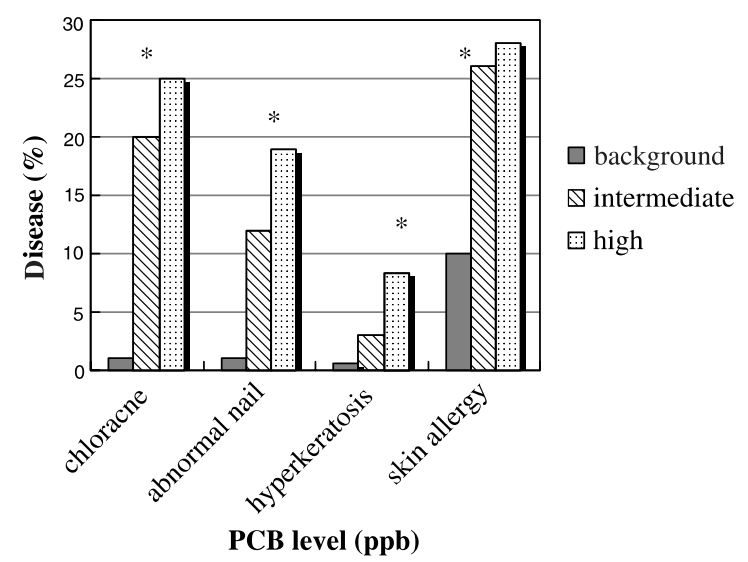

Fig. 2. Disease prevalence according to PCB levels in 19801982. PCB exposed group were divided into "intermediate": PCB levels $<51 \mathrm{ppb}$ and "high": PCB level $\geqslant 51 \mathrm{ppb}$. ${ }^{*} P$ value $<0.001$ by Chi-square test in three groups.

(mean of PCB level: $29.0 \pm 7.3 \mathrm{ppb}$ ); 168 highly exposed (mean of PCB level: $140.0 \pm 7.4 \mathrm{ppb}$ ). Prevalence of skin diseases included chloracne, abnormal nail, hyperkeratosis and skin allergy were significantly increased in Yucheng groups, in a dose-response manner (Fig. 2).

\subsection{Allele frequency in genetic polymorphisms}

Five genetic polymorphisms included AhR-MseI, CYP1A1-MspI, CYP1A1-NcoI, GSTT1, and GSTM1 are shown in 393 Yucheng and 181 background exposure subjects (Table 3 ). The common allele frequency of AhR at coden 554 (Arg) in Yucheng group and background exposure group was 0.69 and 0.66 , comparable to those among Japanese $(0.57 ; n=227)$ and Canadian
Chinese $(0.68 ; n=41)$. Both polymorphisms of CYP1A1 at MspI and NcoI site had common allele frequencies of 0.57 and 0.75 , respectively, in Yucheng population, and 0.60 and 0.77 , respectively, in background exposure. GST-M1 null genotype and GST-T1 null genotype accounted for approximately a half of both Yucheng and background exposure groups.

\subsection{Genetic susceptibility to diseases}

In Yucheng population, logistic regression was done for each PCB exposure level stratum, which demonstrated that GST-M1 null genotype were associated with skin allergy only in the intermediately exposed group $(\mathrm{OR}=3.1 ; 95 \% \mathrm{CI}: 1.5-6.7)$. The other diseases were not associated with the five genetic polymorphisms. The results of single nucleotide polymorphism and diseases were shown in Table 4. Gene-gene interactive effects on skin diseases between three genetic polymorphisms (AhR, CYP1A1 MspI and GSTM1) were shown in Table 5. In people highly exposed to PCBs, the risk of chloracne was associated with combined CYP1A1 MspI mutant $(\mathrm{m} 2 / \mathrm{m} 2)$ and GSTM1 null genotype $(\mathrm{OR}=2.8$; 95\% CI: 1.1-7.6). Among intermediately exposed subjects, GSTM1 null genotype were related to skin allergy in both CYP1A1 genotypic groups (CYP1A1 wild/heterozygote, OR: 2.7; 95\% CI: 1.2-6.1; CYP1A1 mutant, OR: $3.9 ; 95 \%$ CI: $1.2-12.6)$.

\section{Discussion}

This is the first study on genetic susceptibility to PCBs/PCDFs in highly exposed humans. The development of chloracne was more prominent in those with CYP1A1 MspI variant genotype $(\mathrm{m} 2 / \mathrm{m} 2)$ combined 
Table 3

Allele frequency of each genetic polymorphism in Yucheng and background exposure subjects

\begin{tabular}{|c|c|c|c|c|c|c|c|c|c|c|}
\hline \multirow[t]{2}{*}{ Gene } & \multirow[t]{2}{*}{ Polymorphism } & \multicolumn{4}{|c|}{ Yucheng subjects $(n=393)$} & \multicolumn{4}{|c|}{ Background exposure $(n=181)$} & \multirow[t]{2}{*}{$P$-value ${ }^{\mathrm{a}}$} \\
\hline & & $\mathrm{W}$ & $\mathrm{H}$ & M & Af & $\mathrm{W}$ & $\mathrm{H}$ & M & Af & \\
\hline AhR & $\begin{array}{l}\text { MseI } \\
\text { (Arg/Lys) }\end{array}$ & $\begin{array}{l}191 \\
(0.49)\end{array}$ & $\begin{array}{l}157 \\
(0.40)\end{array}$ & $\begin{array}{l}44 \\
(0.11)\end{array}$ & 0.69 & $\begin{array}{l}80 \\
(0.44)\end{array}$ & $\begin{array}{l}79 \\
(0.44)\end{array}$ & $\begin{array}{l}22 \\
(0.12)\end{array}$ & 0.66 & 0.60 \\
\hline \multirow[t]{3}{*}{ CYP1 A1 } & $\begin{array}{l}\text { MspI } \\
(\mathrm{C} / \mathrm{T})\end{array}$ & $\begin{array}{l}131 \\
(0.33)\end{array}$ & $\begin{array}{l}185 \\
(0.47)\end{array}$ & $\begin{array}{l}77 \\
(0.20)\end{array}$ & 0.57 & $\begin{array}{l}69 \\
(0.38)\end{array}$ & $\begin{array}{l}80 \\
(0.44)\end{array}$ & $\begin{array}{l}12 \\
(0.18)\end{array}$ & 0.60 & 0.53 \\
\hline & $\begin{array}{l}\text { NcoI } \\
(\mathrm{A} / \mathrm{G})\end{array}$ & $\begin{array}{l}226 \\
(0.58)\end{array}$ & $\begin{array}{l}139 \\
(0.35)\end{array}$ & $\begin{array}{l}28 \\
(0.07)\end{array}$ & 0.75 & $\begin{array}{l}111 \\
(0.61)\end{array}$ & $\begin{array}{l}56 \\
(0.31)\end{array}$ & $\begin{array}{l}14 \\
(0.08)\end{array}$ & 0.77 & 0.58 \\
\hline & & Null & & Non-null & & Null & & Non-null & & \\
\hline GST & $\mathrm{T} 1$ & $\begin{array}{l}205 \\
(0.52)\end{array}$ & & $\begin{array}{l}188 \\
(0.48)\end{array}$ & & $\begin{array}{l}82 \\
(0.45)\end{array}$ & & $\begin{array}{l}99 \\
(0.55)\end{array}$ & & 0.13 \\
\hline GST & M1 & $\begin{array}{l}213 \\
(0.54)\end{array}$ & & $\begin{array}{l}180 \\
(0.46)\end{array}$ & & $\begin{array}{l}109 \\
(0.60)\end{array}$ & & $\begin{array}{l}72 \\
(0.40)\end{array}$ & & 0.18 \\
\hline
\end{tabular}

$\mathrm{W}$ : wild genotype; H: heterozygous genotype; M: mutant genotype; Af: Allele frequency.

a Chi-square test comparing W, H, M genotype between Yucheng and background exposure groups.

Table 4

The association of genetic polymorphism and diseases by PCB level in Yucheng group

\begin{tabular}{|c|c|c|c|c|c|}
\hline PCB level ${ }^{\mathrm{a}}$ & OR $(95 \% \mathrm{CI})$ & Chloracne & Abnormal nail & Skin allergy & Hyperkeratosis \\
\hline \multirow[t]{5}{*}{ High $(n=168)$} & $\begin{array}{l}\text { CYP1A1-MspI } \\
\text { (m2/m2 vs. } \mathrm{m} 1 / \mathrm{m} 1 \text { or } \mathrm{m} 2)\end{array}$ & $1.9(0.8-4.2)$ & $1.0(0.4-2.4)$ & $1.3(0.6-2.9)$ & $1.5(0.4-4.7)$ \\
\hline & $\begin{array}{l}\text { CYP1A1-NcoI } \\
\text { (Val/Val vs. Ile/Ile or Val) }\end{array}$ & $1.0(0.2-3.5)$ & - & $0.8(0.2-3.0)$ & $1.0(0.1-5.8)$ \\
\hline & $\begin{array}{l}\text { GST-M1 } \\
\text { (null vs. non-null) }\end{array}$ & $1.5(0.8-2.3)$ & $2.3(0.9-7.8)$ & $1.2(0.6-2.4)$ & $1.3(0.4-4.3)$ \\
\hline & $\begin{array}{l}\text { GST-T1 } \\
\text { (null vs. non-null) }\end{array}$ & $1.2(0.6-2.4)$ & $1.5(0.7-3.4)$ & $0.8(0.4-1.7)$ & $1.1(0.4-3.6)$ \\
\hline & $\begin{array}{l}\text { AhR-MseI } \\
\text { (Lys/Lys vs. Arg/Arg or Lys) }\end{array}$ & $2.0(0.6-6.4)$ & $1.3(0.3-4.6)$ & $0.4(0.1-1.7)$ & $0.9(0.1-5.2)$ \\
\hline \multirow[t]{5}{*}{ Intermediate $(n=169)$} & $\begin{array}{l}\text { CYP1A1-MspI } \\
\text { (m2/m2 vs. } \mathrm{m} 1 / \mathrm{m} 1 \text { or } \mathrm{m} 2)\end{array}$ & $0.9(0.3-2.4)$ & - & $1.2(0.5-2.8)$ & - \\
\hline & $\begin{array}{l}\text { CYP1A1-NcoI } \\
\text { (Val/Val vs. Ile/Ile or Val) }\end{array}$ & $0.9(0.1-3.8)$ & $0.7(0.0-4.2)$ & - & - \\
\hline & $\begin{array}{l}\text { GST-M1 } \\
\text { (null vs. non-null) }\end{array}$ & $0.6(0.3-1.2)$ & $0.6(0.2-1.6)$ & $3.1^{*}(1.5-6.7)$ & $1.5(0.2-11.6)$ \\
\hline & $\begin{array}{l}\text { GST-T1 } \\
\text { (null vs. non-null) }\end{array}$ & $0.7(0.3-1.5)$ & $0.6(0.2-1.6)$ & $0.9(0.4-1.7)$ & $0.7(0.1-4.0)$ \\
\hline & $\begin{array}{l}\text { AhR-MseI } \\
\text { (Lys/Lys vs. Arg/Arg or Lys) }\end{array}$ & $1.0(0.3-2.6)$ & $0.3(0.0-1.4)$ & $0.8(0.3-2.0)$ & $1.3(0.1-9.4)$ \\
\hline
\end{tabular}

$(-)$ Means at least one genotype were zero.

* Means that $P$-values $<0.05$.

${ }^{\text {a }}$ PCBs level were classified intermediate and high by median of level in 1980-1982.

with GST-M1 null genotype in highly exposed population. The other genotypes tested, namely, AhR, CYP1A1 NcoI site, GST-T1 null type were not associated with increased susceptibility of developing chloracne. In Yucheng subjects exposed to PCBs/PCDFs at intermediate levels, skin allergy was associated with GSTM1 null genotype.
Humans exposed to TCDD occupationally (Ketchum et al., 1999) and environmentally (Caputo et al., 1988) were well known to develop chloracne. Chloracne is characterized by keratinized cutaneous cysts or comedones (Crow, 1970). Big cysts and comedones were often presented on below outer side of the eye, behind the ear, cheeks, forehead, auricles, trunk, inguinal region and 
Table 5

The interactive effects on skin problems among AhR, CYP1A1 and GSTM1 genotypes by PCB level in Yucheng group

\begin{tabular}{|c|c|c|c|c|c|}
\hline \multirow{2}{*}{\multicolumn{2}{|c|}{$\frac{\text { PCB level }^{\mathrm{a}}}{\text { OR }(95 \% \mathrm{CI})^{\mathrm{c}}}$}} & \multicolumn{2}{|c|}{ PCB intermediate $(n=169)$} & \multicolumn{2}{|c|}{ PCB high $(n=168)$} \\
\hline & & \multirow[t]{2}{*}{ Chloracne } & \multirow[t]{2}{*}{ Skin allergy } & \multirow[t]{2}{*}{ Chloracne } & \multirow[t]{2}{*}{ Skin allergy } \\
\hline$A h R$ & GSTM1 & & & & \\
\hline WH & Non-null & 1 & 1 & 1 & 1 \\
\hline M & Non-null & $0.4(0.1-1.7)$ & $1.2(0.4-4.1)$ & - & - \\
\hline WH & Null & $0.4(0.2-1.0)$ & $2.9(1.3-6.6)^{*}$ & - & - \\
\hline M & Null & $1.6(0.3-7.4)$ & $3.2(0.9-10.4)$ & - & - \\
\hline$C Y P 1 A 1^{\mathrm{b}}$ & GSTM1 & & & & \\
\hline WH & Non-null & 1 & 1 & 1 & 1 \\
\hline M & Non-null & $0.7(0.2-3.6)$ & $0.7(0.2-2.1)$ & $0.4(0.1-1.0)$ & $1.0(0.4-2.7)$ \\
\hline WH & Null & $0.5(0.2-1.2)$ & $2.7(1.2-6.1)^{*}$ & $1.0(0.4-2.3)$ & $1.3(0.6-3.0)$ \\
\hline M & Null & $0.8(0.2-6.0)$ & $3.9(1.2-12.6)^{*}$ & $2.8(1.1-7.6)^{*}$ & $0.6(0.2-2.6)$ \\
\hline$A h R$ & $C Y P 1 A 1$ & & & & \\
\hline WH & WH & 1 & 1 & 1 & 1 \\
\hline WH & $\mathrm{M}$ & $2.3(0.6-15.4)$ & $0.8(0.3-2.5)$ & $0.6(0.3-1.4)$ & - \\
\hline M & WH & $2.2(0.6-14.5)$ & $1.3(0.4-5.0)$ & $0.6(0.2-3.1)$ & - \\
\hline M & M & $0.4(0.1-2.2)$ & $1.1(0.2-7.6)$ & $0.1(0.0-1.5)$ & - \\
\hline
\end{tabular}

$(-)$ Means that at less one of three dummy variables were zero.

* Means that $P$-value $<0.05$.

a PCBs level were classified intermediate and high by median of level in 1980-1982.

${ }^{\mathrm{b}}$ CYP1A1 were digested by MspI restriction enzyme.

${ }^{c}$ Logistic regression model were calculated with independent dummy variables.

external genitalia in PCBs/PCDFs exposure population (Kuratsune et al., 1996). Although the mechanisms mediating chloracne development is not clear, one of the hypotheses suggests that occurrence of chloracne might be secondary to disturbance of Vitamin A (retinol) homeostasis by TCDD, resulting in effects similar to vitamin A deficiency (Nilsson and Hakansson, 2002). TCDD was reported to cause increased oxidation and excretion of vitamin $\mathrm{A}$, and reduced hepatic retinoid levels (Nilsson et al., 2000). Over-oxidation of vitamin A in turn induced acne formation. CYP1A1 has been associated with TCDD-mediated oxidatives stress (Nebert et al., 1993), e.g., CYP1A1 was responsible for the oxidation of $17 \beta$-estradiol to produce catechol estrogens. It is possible that CYP1A1 activity is related to TCDD-induced oxidation of vitamin A.

Genetic polymorphisms in human cytochrome P450 as well as phase II enzymes, such as GST, were related to varied phenotypical expression of enzymes which can influence metabolic activities and toxic effects. CYP1A1 inducibility was shown to be greater in CYP1A1 MspI variant genotype in mitogen-stimulated lymphocytes (Landi et al., 1994), but such differential induction was not associated with genetic polymorphism at NcoI site (Persson et al., 1997). In addition, higher CYP1A1 mRNA inducibility in response to $100 \mathrm{nM}$ TCDD was found in GSTM1 null genotype as compared with non-null genotype in human lymphoblastoid B cells (Vaury et al., 1995). In this study, increased susceptibility to developing chloracne in Yucheng subjects with combination of GSTM1 null genotype and CYP1A1 MspI variant genotype might have been due to more readily induced hepatic enzymes, resulting in more accelerated retinoid metabolism and excretion, leading to abnormal sebocyte differentiation and hyperkeratinization of follicular canal, therefore the development of acne (Paraskevaidis et al., 1998).

It was unclear whether glutathione-S-transferase activity is related to TCDD toxicity. AHH and GST activity were both found significantly depressed in the peripheral lymphocytes among allergic and irritant contact dermatitis subjects, as compared with control (Singh et al., 1982). Whether such depression was related to null genotype in GSTM1 is unknown. In Yucheng people, GSTM1 genotype played an important role in susceptibility to PCBs/PCDFs induced skin allergy, but only among subjects with intermediate levels of exposure. It is possible that in highly exposed subjects, exposure to toxicants was sufficient to produce skin allergy disregard to genotypes. Conversely, among individuals with intermediate exposure, GST-M1 null genotype, thus a lowered capability of detoxifying these toxicants are also required, in order to cause skin allergy.

In conclusion, we found that exposure to PCBs/ PCDFs causes skin lesions, including chloracne, skin allergy, abnormal nail, etc. in a dose-related manner. Genetic polymorphisms such as CYP1A1 and GSTM1 affected susceptibility to developing skin conditions among the exposed individuals. Among those exposed to intermediate levels of PCB/PCDFs, GSTM1 null 
genotype predisposed people to developing skin allergy. Among Yucheng people, chloracne was associated with combined mutant CYP1A1-MspI and GSTM1 null genotypes. Although further studies are warranted to prove such findings since multiple comparisons could have caused false positive results, genotype variations and the related differences in susceptibility should be seriously considered while assessing risk in people exposed to PCBs and PCDFs, and related chemicals.

\section{Acknowledgement}

The study was supported by the National Science Council, Taiwan ROC NSC91-3112-B-006-006, and NSC93-3112-B-006-010.

\section{References}

Alexandrie, A.K., Sundberg, M.I., Seidegard, J., Tornling, G., Rannug, A., 1994. Genetic susceptibility to lung cancer with special emphasis on CYP1A1 and GSTM1: a study on host factors in relation to age at onset, gender and histological cancer types. Carcinogenesis 15, 1785-1790.

Anderson, H.A., 1989. General population exposure to environmental concentration of halogenated biphenyls. In: Kimbrough, R.D., Hansen, A.A. (Eds.), Halogenated Biphenyls, Terphenyls, Naphthalenes, dibenzodioxinx and Related Products. Elsevier, New York, pp. 325-344.

Anttila, S., Hirvonen, A., Husgafvel-Pursiainen, K., Karjalainen, A., Nurminen, T., Vainio, H., 1994. Combined effect of CYP1A1 inducibility and GSTM1 polymorphism on histological type of lung cancer. Carcinogenesis 15, 1133-1135.

Arand, M., Muhlbauer, R., Hengstler, J., Jager, E., Fuchs, J., Winkler, L., Oesch, F., 1996. A multiplex polymerase chain reaction protocol for the simultaneous analysis of the glutathione S-transferase GSTM1 and GSTT1 polymorphisms. Anal. Biochem. 236, 184-186.

Caputo, R., Monti, M., Ermacora, E., Carminati, G., Gelmetti, C., Gianotti, R., 1988. Cutaneous manifestations of tetrachlorodibenzo- $p$-dioxin in children and adolescents. Followup 10 years after the Seveso, Italy, accident. J. Am. Acad. Dermatol. 19, 812-819.

Crow, K.D., 1970. Chloracne. Trans. St. Johns Hosp. Dermatol. Soc. 56, 77-99.

d'Errico, A., Taioli, E., Chen, X., Vineis, P., 1996. Genetic metabolic polymorphisms and the risk of cancer: a review of the literature. Biomarker 1, 149-173.

el-Zein, R., Conforti-Froes, N., Au, W.W., 1997. Interactions between genetic predisposition and environmental toxicants for development of lung cancer. Environ. Mol. Mutagen. 30, 196-204.

Evans, W.E., Relling, M.V., 1999. Pharmacogenomics: translating functional genomics into rational therapeutics. Science 286, 487-491.

Guo, Y.L., Ryan, J.J., Lau, B.P.Y., Yu, M.L., Hsu, C.C., 1997. Blood serum levels of PCBs and PCDFs in Yucheng women 14 years after exposure to toxic rice oil. Arch. Environ. Contam. Toxicol. 33, 104-108.
Guo, Y.L., Yu, M.L., Hsu, C.C., Rogan, W.J., 1999. Chloracne, goiter, skin diseases, arthralgia, and anemia after PCB/PCDF poisoning: 14 year follow-up of the Taiwan Yucheng cohort. Environ. Health Persp. 107, 715-719.

Hayashi, S.I., Watanabe, J., Nakachi, K., Kawajiri, K., 1991. PCR detection of an A/G polymorphism within exon 7 of the CYP1A1 gene. Nucleic Acids Res. 19, 4797.

Jensen, A.A., 1987. Polychlorinated biphenyls (PCBs), polychlorodibenzo-p-dioxins (PCDDs) and polychlorodibenzofurans (PCDFs) in human milk, blood, and adipose tissue. Sci. Total Environ. 64, 259-293.

Ketchum, N.S., Michalek, J.E., Burton, J.E., 1999. Serum dioxin and cancer in veterans of Operation Ranch Hand. Am. J. Epidemiol. 149, 630-639.

Kimbrough, R.D., 1985. Laboratory and human studies on polychlorinated biphenyls (PCBs) and related compounds. Environ. Health Perspect. 59, 99-106.

Kuratsune, M., Yoshimura, T., Matsuzaka, J., Yamaguchi, A., 1971. Yusho, a poisoning caused by rice oil contaminated with polychlorinated biphenyls. HSMHA Health Rep. 86, 1083-1091.

Kuratsune, M., Yoshimura, H., Hori, Y., Okumura, M., Masuda, Y., 1996. Yusho: a human disaster caused by PCBs and related compounds. In: Nakayama, J., Urabe, A., Hori, Y. (Eds.), The Clinical Course of Dermatological Symptoms in Yusho Patients over the Past 25 Years, pp. 183-184.

Lan, C.F., Chen, P.H., Shieh, L.L., Chen, Y.H., 1981. An epidemiological study on polychlorinated biphenyls poisoning in Taichung area. Clin. Med. 7, 96-100.

Landi, M.T., Bertazzi, P.A., Shields, P.G., Clark, G., Lucier, G.W., Garte, S.J., Cosma, G., Caporaso, N.E., 1994. Association between CYP1A1 genotype, mRNA expression and enzymatic activity in humans. Pharmacogenetics 4, 242-246.

Nakayama, J., Hori, Y., Toshitani, S., Asahi, M., 1997. Dermatological findings in the annual examination of the patients with Yusho in 1995-1996. Fukuoka Igaku Zasshi 88, 236-239 (in Japanese).

Nebert, D.W., Puga, A., Vailiou, V., 1993. Role of the Ah receptor and the dioxin-inducible $[\mathrm{Ah}]$ gene battery in toxicity, cancer, and signal transduction. Ann. NY Acad. Sci. 685, 624-640.

Nilsson, C.B., Hakansson, H., 2002. The retinoid signaling system - a target in dioxin toxicity. Crit. Rev. Toxicol. 32, 211-232.

Nilsson, C.B., Hoegberg, P., Trossvik, C., Azais-Braesco, V., Blaner, W.S., Fex, G., Harrison, E.H., Nau, H., Schmidt, C.K., Van Bennekum, A.M., Hakansson, H., 2000. 2,3,7,8tetrachlorodibenzo- $p$-dioxin increases serum and kidney retinoic acid levels and kidney retinol esterification in the rat. Toxicol. Appl. Pharmacol. 169, 121-131.

Paraskevaidis, A., Drakoulis, N., Roots, I., Orfanos, C.E., Zouboulis, C.C., 1998. Polymorphisms in the human cytochrome P-450 1A1 gene (CYP1A1) as a factor for developing acne. Dermatology 196, 171-175.

Pemble, S., Schroder, K.R., Spencer, S.R., Meyer, D.J., Hallier, E., Bolt, H.M., Ketterer, B., Taylor, J.B., 1994. Human glutathione S-transferase theta (GSTT1): cDNA cloning and the characterization of a genetic polymorphism. Biochem. J. 300, 271-276. 
Persson, I., Johansson, I., Ingelman-Sundberg, M., 1997. In vitro kinetics of two human CYP1A1 variant enzymes suggested to be associated with inter-individual differences in cancer susceptibility. Biochem. Biophys. Res. Commun. 231, 227-230.

Reyes, H., Reisz-Porszasz, S., Hankinson, O., 1992. Identification of the $\mathrm{Ah}$ receptor nuclear translocator protein (ARNT) as a component of the DNA binding form of the Ah receptor. Science 256, 1193-1195.

Seidegard, J., Pero, R.W., Miller, D.G., Beattie, E.J., 1986. A glutathione transferase in human leukocytes as a marker for the susceptibility to lung cancer. Carcinogenesis 7, 751-753.

Shields, P.G., Bowman, E.D., Harrington, A.M., Doan, V.T., Weston, A., 1993. Polycyclic aromatic hydrocarbon-DNA adducts in human lung and cancer susceptibility genes. Cancer Res. 53, 3486-3492.

Shimada, T., Inoue, K., Suzuki, Y., Kawai, T., Azuma, E., Nakajima, T., Shindo, M., Kurose, K., Sugie, A., Yamagishi, Y., Fujii-Kuriyama, Y., Hashimoto, M., 2002. Arylhydrocarbon receptor-dependent induction of liver and lung cytochromes $\mathrm{P} 450$ 1A1, 1A2, and 1B1 by polycyclic aromatic hydrocarbons and polychlorinated biphenyls in genetically engineered C57BL/6J mice. Carcinogenesis 23, 1199-1207.

Singh, N., Hamann, K., Clausen, J., 1982. Decreased lymphocyte aryl hydrocarbon hydroxylase and glutathione Stransferase activities in patients with hand dermatitis. Acta Derm. Venereol. 62, 61-63.

Sorsa, M., Osterman-Golkar, S., Peltonen, K., Saarikoski, S.T., Sram, R., 1996. Assessment of exposure to butadiene in the process industry. Toxicology 113, 77-83.
Spencer, D.L., Masten, S.A., Lanier, K.M., Yang, X., Grassman, J.A., Miller, C.R., Sutter, T.R., Lucier, G.W., Walker, N.J., 1999. Quantitative analysis of constitutive and 2,3,7,8tetrachlorodibenzo- $p$-dioxin-induced cytochrome P450 1B1 expression in human lymphocytes. Cancer Epidemiol. Biomarkers Prev. 8, 139-142.

Van Leeuwen, F.X., Feeley, M., Schrenk, D., Larsen, J.C., Farland, W., Younes, M., 2000. Dioxins: WHO's tolerable daily intake (TDI) revisited. Chemosphere 40, 10951101.

Vanden Heuvel, J.P., Clark, G.C., Thompson, C.L., McCoy, Z., Miller, C.R., Lucier, G.W., Bell, D.A., 1993. CYP1A1 mRNA levels as a human exposure biomarker: use of quantitative polymerase chain reaction to measure CYP1A1 expression in human peripheral blood lymphocytes. Carcinogenesis 14, 2003-2006.

Vaury, C., Laine, R., Noguiez, P., de Coppet, P., Jaulin, C., Praz, F., Pompon, D., Amor-Gueret, M., 1995. Human glutathione S-transferase M1 null genotype is associated with a high inducibility of cytochrome p450 1A1 gene transcription. Cancer Res. 55, 5520-5523.

Wong, M.Y., Okey, A.B., Harper, P.A., 2001. Human aryl hydrocarbon receptor polymorphisms: that result in loss of CYP1A1 induction. Biochem. Biophys. Res. Commun. 288, 990-996.

Yuspa, S.H., Shields, P.G., 2001. Etiology of cancer: chemical factors. In: De Vita, J., Hellman, V.T.S., Rosenberg, S.A. (Eds.), Cancer: Principles and Practice of Oncology. Lippincott Williams \& Wilkins, Philadelphia, pp. 179193. 